\title{
Magnesium Oxide Nano Particles Effects on Utilization of Soil Phosphorus by Maize (Zea mays L.) Plant
}

\author{
Tapan Adhikari* \\ ICAR-Indian Institute of Soil Science, Nabibagh, Berasia Road, \\ Bhopal-462038, M.P., India \\ *Corresponding author
}

\section{A B S T R A C T}

\section{Keywords \\ $\mathrm{MgO}$ nano particle, Maize, Soils, Phosphatase, Phytase}

Article Info

Accepted:

04 September 2019

Available Online:

10 October 2019
Magnesium ( $\mathrm{Mg}$ ) is the structural component of chlorophyll and polysaccharides and also an activator of several enzymes. Magnesium plays an important role in photosynthesis. An attempt was made in the present investigation on utilizing this property for increasing rate of photosynthesis of maize plant and subsequently higher root exudations which enhance the microbial activities in soil. Green house experiments were conducted to evaluate the effect of $\mathrm{MgO}$ nano particles spray on maize plant (Zea mays L.) in three benchmark soils of India which are phosphorus (P) deficient. Results revealed that application of $\mathrm{MgO}$ nano particles spray $10 \mathrm{mg} / \mathrm{L}$ (viz. 15,28 , and 35 days after sowing) enhanced the enzymatic activities like phytase and phosphatase particularly in roots of $\mathrm{P}$ deficient plant. With the application of both $\mathrm{P}$ doses (viz. $0,13,26$, and $52 \mathrm{mg} \mathrm{kg}^{-1}$ ) and $\mathrm{MgO}$ nano particles spray increased the different growth parameters of plants like root length, root volume, dry weight of shoot and root etc. irrespective of soils. The results can enhance our understanding on the role of $\mathrm{MgO}$ nano particles spray in plant root exudation and as well as the availability of soil $\mathrm{P}$. These findings are of great help towards building a comprehensive understanding of the potential impact of $\mathrm{MgO}$ nano-particles on phosphorus nutrition of plant and soil health.

\section{Introduction}

Currently, nanotechnology holds a prominent position in boosting agriculture and permits broad advances in agricultural research. In industry nano- $\mathrm{MgO}$ has been extensively used for several decades. But its application in agricultural field is still not emphasized and practiced so as to increase the nutrient use efficiency. Before application in field characterization of nano particles is essential to understand its behaviour and reaction kinetics in soils and plants. Magnesium is the most important essential secondary nutrient, which is required to enhance the productivity of the crop. Nano-scale $\mathrm{MgO}$ exhibits unique optical electronic, magnetic, thermal, mechanical, and chemical properties, due to its 
characteristic structures. In this investigation the optical property of $\mathrm{MgO}$ nano particles was given importance which subsequently increased the plant root exudation and also helped to increase the energy supply and supply of $\mathrm{C}$ skeleton compounds to phosphorus mobilizing microorganisms. This approach would enable in breaking of existing barriers in utilization of native $\mathrm{P}$ and reduce dependence on imported $\mathrm{P}$ fertilizers. There are no studies on effect of nano-particles on root exudation but it is envisaged that higher photo energy (photosynthesis) available through root exudates to soil system would positively create favourable conditions for microbial growth and consequently enhance the native $\mathrm{P}$ solubilization. Maize is now widely cultivated in India, and a greater weight of maize is produced each year than any other grain. The importance of maize or corn lies in its wide variety of applications besides serving as human food and animal feed. Phosphorus $(\mathrm{P})$ is one of the main plant nutrients, the lack of which limits plant growth. In most soils, the concentration of orthophosphate in solution is low and must be replenished from other pools of soil $\mathrm{P}$ to satisfy plant requirements (Richardson and Simpson 2011). Thus, phosphate-mobilizing microorganisms may be used to increase $\mathrm{P}$ availability to plants (Kalayu, 2019). The greatest challenge in Indian agriculture in the coming decades is to increase production with ecological sustainability and in order to achieve that there is a need for optimum utilization of fertilizers. To address the issues relating to increase fertilizer use efficiency, development of new agricultural technologies will be crucial in meeting the ecological needs. Many studies have reported that nano particles have favorable effects on plant growth and development. Still the knowledge available on the positive or negative effects of some nano-particles on the physiology and biochemistry of plants is meager, and does not convey any clear evidence on this issue.
Against this backdrop, the present investigation was carried out to investigate the effect of $\mathrm{MgO}$ nano particles spray on maize plant for the utilization of soil phosphorus.

\section{Materials and Methods}

\section{Soil sampling and analysis}

Surface soil samples $(0-15 \mathrm{~cm})$ were collected from P deficient field from Jodhpur, Bhopal, Betul. The soils are respectively classified as Aridisol (Typic Haplustalfs), Vertisol (Typic Haplustert), and Alfisol (Typic Torripsamments). Composite surface soil samples from the above sites were processed, sieved through a $2 \mathrm{~mm}$ sieve and analyzed for physico-chemical properties by following the standard procedure (Page, 1982). Available phosphorous in the soil was determined by spectrophotometry (Olsen, 1954).

\section{Test NPs}

The MgO NPs were purchased from SigmaAldrich Company, St. Louis, MO, USA.

\section{Dynamic Light Scattering (DLS) Analysis}

Particle size analyzer (Malvern, USA) was used for size measurement and confirmation of nano particles size distribution.

\section{Green house experiment}

Green house experiments were conducted with three different soils of India. Four levels of $\mathrm{P}$ (viz. $0,13,26$, and $52 \mathrm{ppm}$ as reagent grade $\mathrm{KH}_{2} \mathrm{PO}_{4}$ were applied in solution form in soil and the treated soil was then mixed thoroughly and flooded with distilled water for three days prior to transplanting of maize crop. Basal application of NK at the rate of $100-60 \mathrm{mg} \mathrm{kg}^{-}$ ${ }^{1}$ soil was made through AR-grade urea and $\mathrm{KCl}$, respectively. Each treatment was replicated for thrice. A pot (height $13.5 \mathrm{~cm}$ 
and inside diameter $11 \mathrm{~cm}$ ) culture experiment was conducted in a green house. Temperature, light and humidity were not regulated. Temperature varied between 20 and $35{ }^{\circ} \mathrm{C}$, photo flux density at leaf level about $400 \mu$ mol $\mathrm{cm}^{-2}$, humidity varied from $70-80 \%$. Spray of $\mathrm{Mg}$ nano particle $(<50 \mathrm{~nm}), 10 \mathrm{ppm}$ (viz. 15, 28, and 35 days after sowing) were applied on maize plant. The soils were watered to field capacity with deionized water (gravimetric field capacity water content was $27 \%$ for Vertisol, $10 \%$ for the Alfisol, and $16 \%$ for the Aridisols) and allowed to incubate for 15 days in the green house before sowing. The pots were watered daily to field capacity with deionized water re-randomized every second day. The soil was sown with maize (Zea mays) plant. Ten germinated seeds were sown at $1 \mathrm{~cm}$ depth into each pot. Plants were thinned to 5 plants per pot at the 2-leaf stage, leaving 5 uniform plants. Crop was harvested after 45 days of sowing. The plant shoot and root sample for each pot were combined, washed thoroughly with distilled water, and weight after drying at $70{ }^{\circ} \mathrm{C}$ for 2 days. All dried plant sample were digested with mixture of nitric acid- perchloric acid (9:4). Phosphorous concentration in the digested plant sample was determined with an Inductively Coupled Plasma-Optical Emission Spectrometry (ICP-OES).

\section{Seeds}

Seeds maize (Zea mays L.) plant was purchased from National Seed Corporation, India. The average germination rates of both the plants were greater than $90 \%$ as shown by a preliminary study. Seeds were kept in a dry place in the dark under room temperature before use.

\section{Root studies}

The root samples collected after harvesting were initially washed with distilled water to make them free from any soil particles and following observations were made:

\section{Root length}

Root length was computed using the modified version of Newman (1966) formula proposed by Tennant (1975) as:

Root Length: 11/14* number of intersections (N) * grid unit.

\section{Root volume}

Root volume was determined by displacement method (Mishra and Ahmed, 1987).

\section{Enzyme assay}

\section{Phytase activity}

The enzyme activity was determined by following Heinonen and Lahti (1981) method.

\section{Phosphatase activity}

The enzyme activity was determined following the method described by Parfsh (1974).

\section{Statistical analysis}

Each treatment was conducted with three replicates, and the results were presented as mean \pm SD (standard deviation).

\section{Results and Discussion}

\section{Physico chemical properties of experimental soils}

The experimental soils varied in $\mathrm{pH}$ from 5.65 to 8.98 , EC from 0.24 to $0.40 \mathrm{dS} \mathrm{m}^{-1}$, organic carbon content from 2.2 to $6.6 \mathrm{~g} \mathrm{~kg}^{-1}$, cation exchange capacity from 7 to $45 \mathrm{cmol}(\mathrm{p}+)$ $\mathrm{kg}^{-1}$, clay content from 7.87 to $55.5 \%$ and 
$\mathrm{CaCO}_{3}$ content from trace to $2.7 \%$. The available $\mathrm{P}$ content varied from 4.58 to 6.12 $\mathrm{mg} \mathrm{kg}^{-1}$ (Table 1).

\section{TEM study of nano-MgO particles}

The TEM image of the magnesium oxide NPs revealed at their spherical, truncated and uneven nature with an average size of approximately $50 \pm 20 \mathrm{~nm}$ (Figure 1).

The TEM micrographs indicated that the copper oxide nano particles were mono dispersed with a narrow size distribution and near spherical morphology. Analysis of particles in TEM monograph indicated hexagonal particles with the average size of 50 nm.

\section{DLS study of nano-MgO particles}

The size of nano $\mathrm{MgO}$ particles were measured by dynamic light scattering (DLS) technique using particle size analyzer (Figure 2) and it was found that the $\mathrm{MgO}$ particle recorded a size of $<50 \mathrm{~nm}$.

\section{Effect of MgO nano-particles spray on dry matter yield of maize plant}

A perusal of the data (Table 2-7) revealed that the biomass yield of maize plant harvested after 45 days of sowing in different soils like Vertisol, Alfisol, and Aridisol showed distinctly different response to $\mathrm{P}$ nutrition to maize plant treated with and without $\mathrm{MgO}$ nano particles spray. The shoot and root dry matter yield of maize plant treated with $\mathrm{MgO}$ NP spray recorded 0.67 and 0.66 times more yield respectively than the plant without any $\mathrm{MgO}$ NP spray in Vertisol (Table 2 and 3) of Bhopal region. Similarly in case of root length and root volume of treated plant showed 0.64 and 0.57 times more growth than the untreated plant. Experimental results also revealed that with the increasing rate of application of different doses of $\mathrm{P}\left(0,13,26\right.$ and $\left.52 \mathrm{mg} \mathrm{kg}^{-1}\right)$, enhanced the dry matter yield of shoot and root of maize plant. The highest dry matter yields of shoot and root $(2.95 \mathrm{~g}$ and $0.29 \mathrm{~g}$ ) was recorded at the dose of $52 \mathrm{mg} \mathrm{P} \mathrm{kg}^{-1}$ in Vertisol. The increase in growth and yield parameters of maize plant was observed and the difference could be attributed to additive effect of the $10 \mathrm{ppm} \mathrm{MgO} \mathrm{NP}$ spray. Root length and root volume of treated plant showed $990 \mathrm{~cm}$ and $28 \mathrm{cc}$ in comparison to control plant $387 \mathrm{~cm}$ and $7 \mathrm{cc}$ respectively.

The stunted growth and low yield was observed for control plant and the reason could be due to reduction in soil nutrient supply to the crop without any MgO NP spray.

The highest $\mathrm{P}$ content in shoot and root i.e. $0.15 \%$ and $0.11 \%$ respectively was recorded in case of higher dose of $\mathrm{P}$ application $(52 \mathrm{mg}$ $\left.\mathrm{kg}^{-1}\right)$. For a better understanding of the effect of $\mathrm{MgO} \mathrm{NP}$ spray on maize plant in different soils, however, studies on multiple soils like Vertisol, Alfisol, and Aridisol were conducted. In case of Alfisol, the $\mathrm{MgO} \mathrm{NP}$ treated shoot and root dry matter yield were also shown an increasing trend i.e. 0.55 and 0.57 times more than untreated plant (Table 4 and 5). The root length and root volume recorded 0.54 and 0.51 times more than the plant without $\mathrm{MgO} \mathrm{NP}$ spray.

The increase in biomass production of maize plant could be as a result of good $\mathrm{P}$ supply facilitated by application of $\mathrm{MgO} \mathrm{NP}$ spray that resulted in good crop growth and increase yield. The beneficial effects were attributed to the improvement in soil nutrition. Another possible reason could be that the improved soil $\mathrm{P}$ status with the $\mathrm{MgO} \mathrm{NP}$ spray encouraged root growth and nutrient use. Thus growth and yield attributes increased. Amongst the soils compared, the Aridisol recorded lowest dry matter yield of shoot and root (Table 6 and 7). 
Table.1 Physico- chemical properties of the experimental soils

\begin{tabular}{|c|c|c|c|c|c|c|c|c|}
\hline \multirow[t]{2}{*}{$\begin{array}{l}\text { Sl. } \\
\text { No. }\end{array}$} & \multirow[t]{2}{*}{ Soil sub group and Site } & \multirow[t]{2}{*}{$\begin{array}{c}\text { pH } \\
(1: 2.5 \\
\left.\mathrm{H}_{2} \mathrm{O}\right)\end{array}$} & \multirow[t]{2}{*}{$\begin{array}{c}\mathrm{EC} \\
\left(\mathrm{dS} \mathrm{m}^{-1}\right)\end{array}$} & \multirow[t]{2}{*}{$\begin{array}{c}\text { Organic } \\
\text { Carbon } \\
(\%)\end{array}$} & \multirow[t]{2}{*}{$\begin{array}{c}\text { CEC } \\
\text { cmol } \\
(p+) k^{-1}\end{array}$} & Clay & $\mathrm{CaCO}_{3}$ & \multirow[t]{2}{*}{$\begin{array}{c}\text { Available P } \\
\text { (mg/kg) }\end{array}$} \\
\hline & & & & & & \multicolumn{2}{|c|}{--------\%---------- } & \\
\hline 1 & $\begin{array}{c}\text { Bhopal } \\
\text { Typic Ustrochrept }\end{array}$ & 7.85 & 0.40 & 0.66 & 45.0 & 55.50 & 2.7 & 5.85 \\
\hline 2 & $\begin{array}{c}\text { Betul } \\
\text { Typic Haplustalf }\end{array}$ & 5.65 & 0.35 & 0.40 & 8.0 & 24.9 & Tr. & 4.58 \\
\hline 3 & $\begin{array}{c}\text { Jodhpur } \\
\text { Typic Torripsamments }\end{array}$ & 8.98 & 0.24 & 0.22 & 7.0 & 7.87 & 1.80 & 6.12 \\
\hline
\end{tabular}

Table.2 Physiological parameters of maize plant grown in Vertisol with $\mathrm{MgO}$ nano particle spray

\begin{tabular}{|c|c|c|c|c|c|c|c|c|c|}
\hline $\begin{array}{l}\text { Sl. } \\
\text { No. }\end{array}$ & $\begin{array}{c}\text { P } \\
\text { levels } \\
\text { (mg/kg) }\end{array}$ & $\begin{array}{l}\text { Dry shoot } \\
\text { wt (g) }\end{array}$ & $\begin{array}{c}\text { Dry root wt } \\
\text { (g) }\end{array}$ & $\begin{array}{l}\text { Root } \\
\text { length } \\
\text { (cm) }\end{array}$ & $\begin{array}{c}\text { Root } \\
\text { Volume } \\
\text { (cc) }\end{array}$ & $\begin{array}{c}\text { Phytase activity } \\
\text { (Nitrite } \\
\mu \mathrm{mol} / \mathrm{hr}) \\
\text { (Root) }\end{array}$ & $\begin{array}{c}\text { Acid } \\
\text { Phosphatase } \\
\text { activity } \\
\mu \mathrm{mol} \mathrm{h}^{-1} \mathbf{g}^{-1} \\
\text { (Root) }\end{array}$ & $\begin{array}{l}\text { Shoot P } \\
\text { content } \\
(\%)\end{array}$ & $\begin{array}{c}\text { Root P } \\
\text { content } \\
(\%)\end{array}$ \\
\hline 1 & 0 & $0.52 \pm 0.02$ & $0.09 \pm 0.007$ & $387 \pm 1.50$ & $7 \pm 0.20$ & $30 \pm 0.55$ & $12.5 \pm 0.30$ & $0.02 \pm 0.001$ & $0.01 \pm 0.001$ \\
\hline 2 & 13 & $1.15 \pm 0.01$ & $0.15 \pm 0.008$ & $560 \pm 2.10$ & $13 \pm 0.65$ & $22 \pm 0.31$ & $8.20 \pm 0.25$ & $0.08 \pm 0.002$ & $0.06 \pm .004$ \\
\hline 3 & 26 & $2.90 \pm 0.07$ & $0.26 \pm 0.01$ & $940 \pm 3.20$ & $25 \pm 0.70$ & $12 \pm 0.25$ & $4.30 \pm 0.15$ & $0.11 \pm 0.011$ & $0.09 \pm 0.005$ \\
\hline 4 & 52 & $2.95 \pm 0.06$ & $0.29 \pm 0.01$ & $990 \pm 5.0$ & $28 \pm 0.68$ & $5.5 \pm 0.20$ & $3.10 \pm 0.25$ & $0.15 \pm 0.03$ & $0.11 \pm 0.02$ \\
\hline
\end{tabular}

Each value is the Mean \pm SD of three replicates 
Table.3 Physiological parameters of maize plant grown in Vertisol soil without $\mathrm{MgO}$ nano particle spray

\begin{tabular}{|c|c|c|c|c|c|c|c|c|c|}
\hline Sl.No. & $\begin{array}{c}P \\
\text { levels } \\
\text { (mg/kg } \\
\text { ) }\end{array}$ & $\begin{array}{c}\text { Dry shoot } \\
\text { wt (g) }\end{array}$ & $\begin{array}{l}\text { Dry root wt } \\
(\mathrm{g})\end{array}$ & $\begin{array}{l}\text { Root } \\
\text { length } \\
(\mathrm{cm})\end{array}$ & $\begin{array}{c}\text { Root Volume } \\
\text { (cc) }\end{array}$ & $\begin{array}{c}\text { Phytase activity } \\
\text { (Nitrite } \mu \mathrm{mol} / \mathrm{hr} \text { ) } \\
\text { (Root) }\end{array}$ & $\begin{array}{c}\text { Acid } \\
\text { Phosphatase } \\
\text { activity } \\
\mu \mathrm{mol} \mathrm{h}^{-1} \mathrm{~g}^{-1} \\
\text { (Root) }\end{array}$ & $\begin{array}{c}\text { Shoot P } \\
\text { content } \\
(\%)\end{array}$ & $\begin{array}{l}\text { Root P } \\
\text { content } \\
(\%)\end{array}$ \\
\hline 1 & 0 & $0.35 \pm 0.03$ & $0.06 \pm 0.006$ & $250 \pm 1.10$ & $4 \pm 0.10$ & $20 \pm 0.40$ & $8.50 \pm 0.30$ & $0.008 \pm 0.001$ & $0.005 \pm 0.001$ \\
\hline 2 & 13 & $0.90 \pm 0.01$ & $0.09 \pm 0.002$ & $400 \pm 2.50$ & $8 \pm 0.55$ & $15 \pm 0.21$ & $4.20 \pm 0.20$ & $0.04 \pm 0.002$ & $0.02 \pm .003$ \\
\hline 3 & 26 & $1.85 \pm 0.06$ & $0.19 \pm 0.01$ & $750 \pm 5.00$ & $16 \pm 0.60$ & $7 \pm 0.22$ & $2.10 \pm 0.05$ & $0.08 \pm 0.004$ & $0.05 \pm 0.004$ \\
\hline 4 & 52 & $1.99 \pm 0.07$ & $0.21 \pm 0.01$ & $780 \pm 5.30$ & $18 \pm 0.65$ & $5 \pm 0.20$ & $1.30 \pm 0.06$ & $0.12 \pm 0.04$ & $0.08 \pm 0.01$ \\
\hline
\end{tabular}

Each value is the Mean $\pm \mathrm{SD}$ of three replicates

Table.4 Physiological parameters of maize plant grown in Alfisol with $\mathrm{MgO}$ nano particle spray

\begin{tabular}{|c|c|c|c|c|c|c|c|c|c|}
\hline Sl.No. & $\begin{array}{c}\text { P } \\
\text { levels } \\
(\mathrm{mg} / \\
\mathrm{kg})\end{array}$ & $\begin{array}{l}\text { Dry shoot } \\
\text { wt (g) }\end{array}$ & $\begin{array}{l}\text { Dry root wt } \\
(\mathrm{g})\end{array}$ & $\begin{array}{l}\text { Root } \\
\text { length } \\
\text { (cm) }\end{array}$ & $\begin{array}{c}\text { Root } \\
\text { Volume } \\
\text { (cc) }\end{array}$ & $\begin{array}{c}\text { Phytase activity } \\
\text { (Nitrite } \\
\mu \mathrm{mol} / \mathrm{hr}) \\
\text { (Root) }\end{array}$ & $\begin{array}{c}\text { Acid } \\
\text { Phosphatase } \\
\text { activity } \\
\mu \text { mol h}^{-1} \mathbf{g}^{-1} \\
\text { (Root) }\end{array}$ & $\begin{array}{l}\text { Shoot } P \\
\text { content } \\
(\mathrm{mg} / \mathrm{kg})\end{array}$ & $\begin{array}{l}\text { Root P } \\
\text { content } \\
(\mathrm{mg} / \mathrm{kg})\end{array}$ \\
\hline 1 & 0 & $0.36 \pm 0.03$ & $0.07 \pm 0.005$ & $220 \pm 1.50$ & $5.80 \pm 0.20$ & $35 \pm 0.40$ & $16 \pm 0.50$ & $150 \pm 2.0$ & $85 \pm 1.0$ \\
\hline 2 & 13 & $0.65 \pm 0.04$ & $0.11 \pm 0.004$ & $415 \pm 3.50$ & $9.51 \pm 0.55$ & $25 \pm 0.11$ & $12 \pm 0.30$ & $570 \pm 3.0$ & $300 \pm 3.0$ \\
\hline 3 & 26 & $1.25 \pm 0.06$ & $0.19 \pm 0.01$ & $780 \pm 5.00$ & $19.50 \pm 0.65$ & $16 \pm 0.10$ & $6.80 \pm 0.05$ & $750 \pm 6.5$ & $560 \pm 3.0$ \\
\hline 4 & 52 & $1.95 \pm 0.08$ & $0.23 \pm 0.02$ & $858 \pm 5.50$ & $22.30 \pm 0.70$ & $8 \pm 0.05$ & $4.30 \pm 0.06$ & $990 \pm 7.2$ & $780 \pm 4.0$ \\
\hline
\end{tabular}

Each value is the Mean $\pm \mathrm{SD}$ of three replicates 
Table.5 Physiological parameters of maize plant grown in Alfisol without MgO nano particle spray

\begin{tabular}{|c|c|c|c|c|c|c|c|c|c|}
\hline Sl.No. & $\begin{array}{l}\text { P levels } \\
(\mathrm{mg} / \mathrm{kg})\end{array}$ & $\begin{array}{c}\text { Dry shoot } \\
\text { wt (g) }\end{array}$ & $\begin{array}{c}\text { Dry root wt } \\
\text { (g) }\end{array}$ & $\begin{array}{l}\text { Root } \\
\text { length } \\
(\mathbf{c m})\end{array}$ & $\begin{array}{c}\text { Root Volume } \\
\text { (cc) }\end{array}$ & $\begin{array}{c}\text { Phytase activity } \\
\text { (Nitrite } \mu \mathrm{mol} / \mathrm{hr} \text { ) } \\
\text { (Root) }\end{array}$ & $\begin{array}{c}\text { Acid } \\
\text { Phosphatase } \\
\text { activity } \\
\mu \mathrm{mol} \mathrm{h}^{-1} \mathbf{g}^{-1} \\
\text { (Root) }\end{array}$ & $\begin{array}{l}\text { Shoot P } \\
\text { content } \\
(\%)\end{array}$ & $\begin{array}{c}\text { Root P } \\
\text { content } \\
(\%)\end{array}$ \\
\hline 1 & 0 & $0.20 \pm 0.01$ & $0.04 \pm 0.004$ & $120 \pm 1.00$ & $3.0 \pm 0.15$ & $22.1 \pm 0.20$ & $9.2 \pm 0.30$ & $60 \pm 1.0$ & $40 \pm 1.0$ \\
\hline 2 & 13 & $0.45 \pm 0.02$ & $0.07 \pm 0.003$ & $310 \pm 2.20$ & $5.1 \pm 0.20$ & $18 \pm 0.11$ & $5.1 \pm 0.20$ & $220 \pm 2.0$ & $135 \pm 0.15$ \\
\hline 3 & 26 & $0.85 \pm 0.04$ & $0.10 \pm 0.01$ & $585 \pm 5.00$ & $9.2 \pm 0.35$ & $9.2 \pm 0.18$ & $2.5 \pm 0.008$ & $450 \pm 3.5$ & $310 \pm 2.0$ \\
\hline 4 & 52 & $0.98 \pm 0.06$ & $0.15 \pm 0.01$ & $710 \pm 5.30$ & $12.5 \pm 0.42$ & $6.5 \pm 0.08$ & $1.6 \pm 0.006$ & $770 \pm 5.5$ & $500 \pm 3.5$ \\
\hline
\end{tabular}

Each value is the Mean \pm SD of three replicates

Table.6 Physiological parameters of maize plant grown in Aridisol with $\mathrm{MgO}$ nano particle spray

\begin{tabular}{|c|c|c|c|c|c|c|c|c|c|}
\hline $\begin{array}{l}\text { Sl. } \\
\text { No. }\end{array}$ & $\begin{array}{c}\text { P } \\
\text { levels } \\
\text { (mg/kg) }\end{array}$ & $\begin{array}{c}\text { Dry shoot } \\
\text { wt (g) }\end{array}$ & $\begin{array}{c}\text { Dry root wt } \\
\text { (g) }\end{array}$ & $\begin{array}{c}\text { Root } \\
\text { length } \\
(\mathrm{cm})\end{array}$ & $\begin{array}{c}\text { Root } \\
\text { Volume } \\
\text { (cc) }\end{array}$ & $\begin{array}{c}\text { Phytase activity } \\
\text { (Nitrite } \\
\mu \mathrm{mol} / \mathrm{hr} \text { ) } \\
\text { (Root) }\end{array}$ & $\begin{array}{c}\text { Acid } \\
\text { Phosphatase } \\
\text { activity } \\
\mu \text { mol h}^{-1} \mathbf{g}^{-1} \\
\text { (Root) }\end{array}$ & $\begin{array}{c}\text { Shoot P } \\
\text { content } \\
(\%)\end{array}$ & $\begin{array}{c}\text { Root P } \\
\text { content } \\
(\%)\end{array}$ \\
\hline 1 & 0 & $0.23 \pm 0.01$ & $0.05 \pm 0.003$ & $150 \pm 1.00$ & $4.0 \pm 0.10$ & $39 \pm 0.30$ & $22.5 \pm 0.25$ & $90 \pm 1.5$ & $60 \pm 1.0$ \\
\hline 2 & 13 & $0.50 \pm 0.02$ & $0.09 \pm 0.004$ & $365 \pm 2.50$ & $7.5 \pm 0.15$ & $30 \pm 0.21$ & $15.2 \pm 0.15$ & $350 \pm 2.5$ & $255 \pm 1.5$ \\
\hline 3 & 26 & $0.96 \pm 0.03$ & $0.15 \pm 0.008$ & $680 \pm 4.00$ & $14.2 \pm 0.40$ & $20 \pm 0.15$ & $9.3 \pm 0.008$ & $430 \pm 4.0$ & $385 \pm 2.5$ \\
\hline 4 & 52 & $1.15 \pm 0.05$ & $0.19 \pm 0.01$ & $715 \pm 5.50$ & $16.5 \pm 0.45$ & $11 \pm 0.08$ & $5.2 \pm 0.006$ & $650 \pm 6.2$ & $470 \pm 3.5$ \\
\hline
\end{tabular}

Each value is the Mean \pm SD of three replicates 
Table.7 Physiological parameters of maize plant grown in Aridisol without $\mathrm{MgO}$ nano particle spray

\begin{tabular}{|c|c|c|c|c|c|c|c|c|c|}
\hline $\begin{array}{c}\text { Sl.N } \\
\text { o. }\end{array}$ & $\begin{array}{l}\text { P levels } \\
(\mathrm{mg} / \mathrm{kg})\end{array}$ & $\begin{array}{l}\text { Dry shoot } \\
\text { wt (g) }\end{array}$ & $\begin{array}{c}\text { Dry root wt } \\
(\mathrm{g})\end{array}$ & $\begin{array}{l}\text { Root } \\
\text { length } \\
(\mathbf{c m})\end{array}$ & $\begin{array}{c}\text { Root Volume } \\
\text { (cc) }\end{array}$ & $\begin{array}{c}\text { Phytase activity } \\
\text { (Nitrite } \mu \mathrm{mol} / \mathrm{hr} \text { ) } \\
\text { (Root) }\end{array}$ & $\begin{array}{c}\text { Acid } \\
\text { Phosphatase } \\
\text { activity } \\
\mu \mathrm{mol} \mathrm{h}^{-1} \mathbf{g}^{-1} \\
\text { (Root) }\end{array}$ & $\begin{array}{c}\text { Shoot P } \\
\text { content } \\
(\%)\end{array}$ & $\begin{array}{c}\text { Root P } \\
\text { content } \\
(\%)\end{array}$ \\
\hline 1 & 0 & $0.15 \pm 0.01$ & $0.03 \pm 0.003$ & $78 \pm 1.50$ & $2.1 \pm 0.10$ & $25.5 \pm 0.30$ & $12.1 \pm 0.25$ & $50 \pm 1.1$ & $30 \pm 1.0$ \\
\hline 2 & 13 & $0.25 \pm 0.02$ & $0.06 \pm 0.005$ & $250 \pm 2.00$ & $3.5 \pm 0.10$ & $20.3 \pm 0.21$ & $6.2 \pm 0.10$ & $120 \pm 2.3$ & $90 \pm 1.8$ \\
\hline 3 & 26 & $0.55 \pm 0.03$ & $0.12 \pm 0.008$ & $458 \pm 3.50$ & $6.9 \pm 0.20$ & $11.2 \pm 0.15$ & $2.88 \pm 0.008$ & $260 \pm 3.5$ & $220 \pm 2.6$ \\
\hline 4 & 52 & $0.68 \pm 0.04$ & $0.17 \pm 0.02$ & $620 \pm 4.50$ & $7.3 \pm 0.35$ & $8.20 \pm 0.08$ & $1.75 \pm 0.006$ & $390 \pm 5.2$ & $285 \pm 3.7$ \\
\hline
\end{tabular}

Each value is the Mean \pm SD of three replicates

Fig.1 Tranmission-electron micograph of the $\mathrm{MgO}$ nanoparticle $(<50 \mathrm{~nm})$
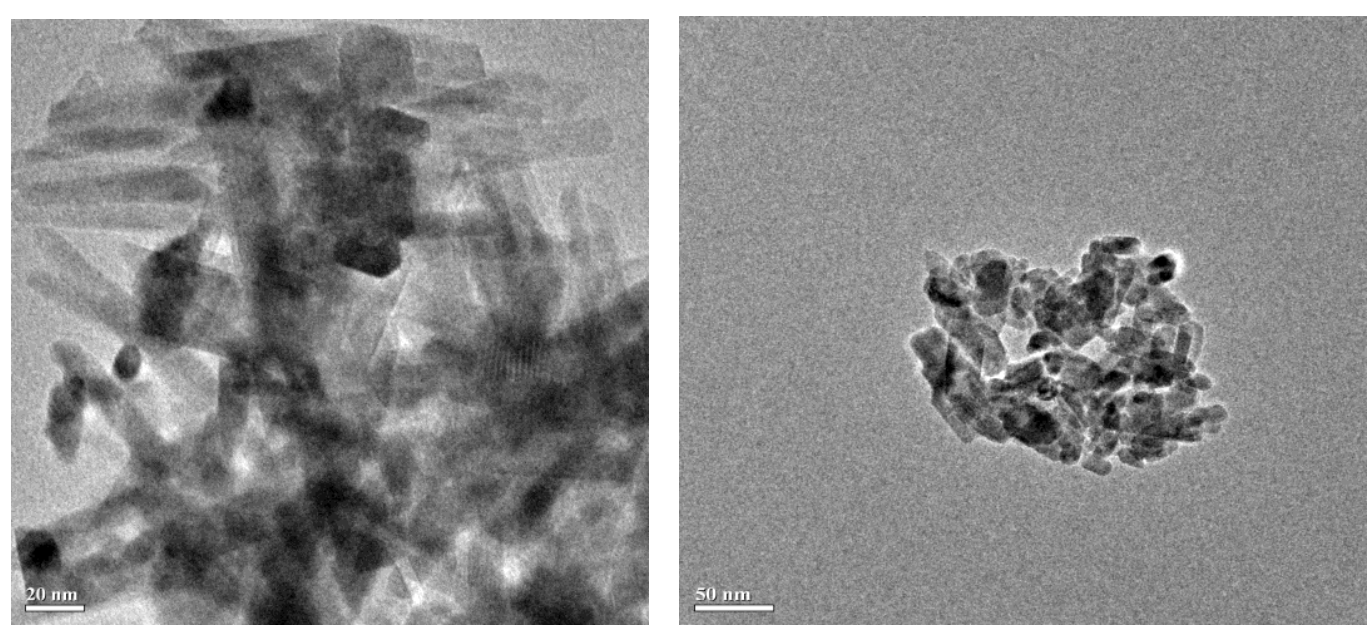
Fig.2 Intensity distribution of $\mathrm{MgO}$ nano particles through Photon Collision Spectroscopy.(Dynamic light scattering techniques)

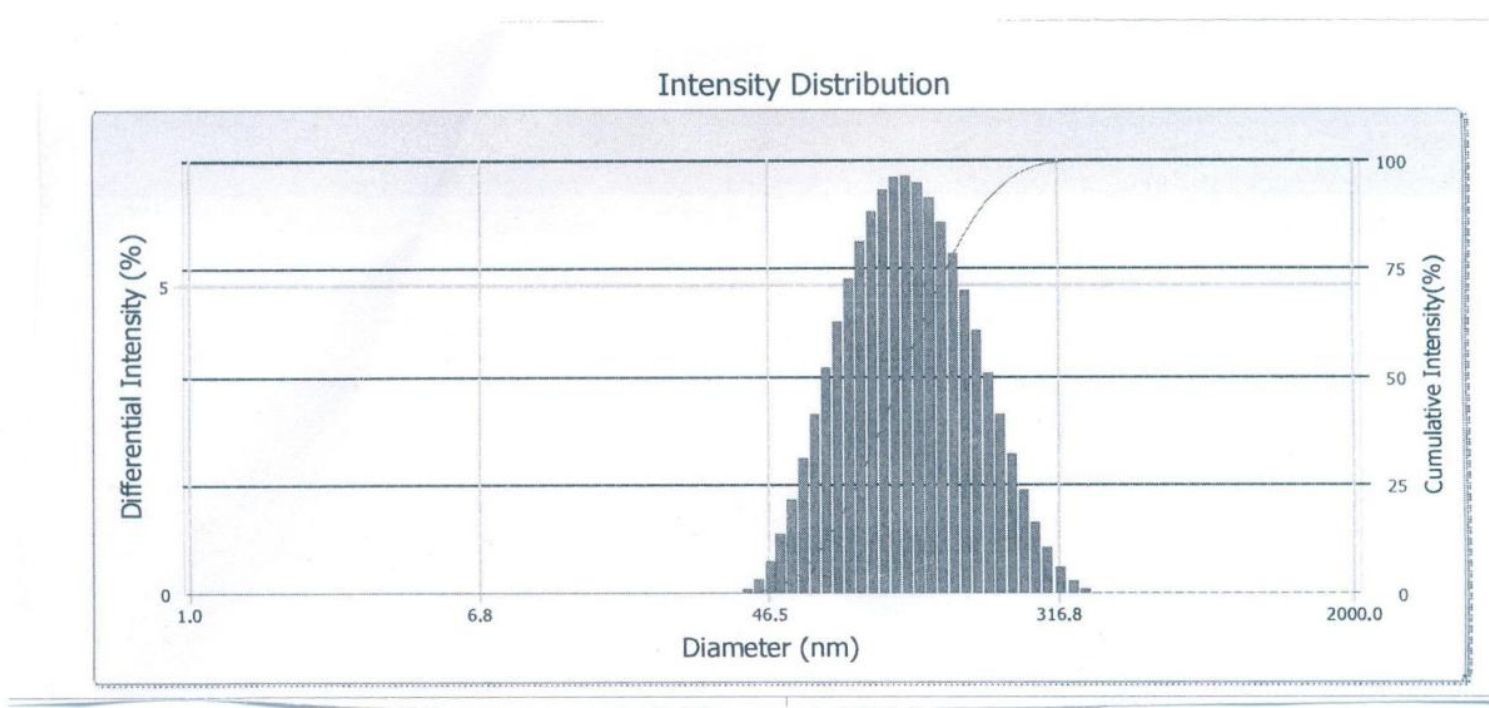

Although the similar trend was observed in relation to $\mathrm{MgO} \mathrm{NP}$ spray to maize plant, growth rate and $\mathrm{P}$ content were recorded the lowest in comparison to other two soils.

\section{Effect of MgO nano-particles spray on enzymatic activity of maize plant}

Spray of $\mathrm{Mg}$ nano particle $(<50 \mathrm{~nm}), 10 \mathrm{mg}$ $\mathrm{kg}^{-1}$ (viz. 15, 28, and 35 days after sowing) were applied on maize plant and experimental results depicted that the activities of two enzymes viz. phytase and acid phosphatase were positively affected by the spray in irrespective of soils (Table 2-7). In Vertisol, the application of $\mathrm{MgO} \mathrm{NP}$ spray increased the phytase enzyme activity 0.57 times more than the non treated plant. Similarly in case of acid phosphatase enzyme, activity was enhanced by 0.66 times. The activities of the two enzymes in Alfisol and Aridisol followed the similar trend. But amongst the soils, the enzymes activities were recorded lowest in Aridisol.

In this investigation $\mathrm{MgO}$ NPs were taken based on its major role in plant photosynthesis and to utilize the impact of size effects on its optical properties. The hypothesis of the present experiment is that $\mathrm{MgO}$ nano-particles improved light absorbance and promoted the photosynthetic activity of plant and thus accelerated plant growth. The increase of carbohydrates may stimulate the growth and activity of microorganisms, which in turn increased the synthesis of enzyme. Uptake and distribution of $\mathrm{MgO}$ nano particles by the plant cells can be exploited for efficient and increased solar energy trapping that might improve the photosynthetic efficiency of plants. The small-sized nano-particles will have higher degree of freedom for movement, and hence, they would be more efficiently absorbed by the plant. Nano-particles when sprayed normally penetrate through the stomata due to its high surface area and kinetic energy. Nano-particles of specific size are capable of penetrating and migrating to different regions of plant cells (Corredor et al., 2009). In this present investigation it was observed that application of $\mathrm{MgO} \mathrm{NP}$ governs a prominent role to enhance the availability of soil P. 
Overall experimental results depicted that 10 $\mathrm{mg} / \mathrm{L} \mathrm{MgO} \mathrm{NP}$ spray on maize leave caused better utilization of applied and native soil $\mathrm{P}$ through root enzymes in irrespective of soils. Enhanced phosphatic enzyme activities and increased growth and yield parameters of maize plant which may be attributed to the fact that $\mathrm{MgO} \mathrm{NP}$ aggravated the photosynthetic and specific metabolic activity of the plant grown in different soils.

\section{Acknowledgements}

Author acknowledged Indian Council of Agriculture Research (ICAR) for the financial support under National Agricultural Innovative Project (NAIP).

\section{References}

Corredor E, Testillano P S, Coronado M J, González-Melendi P, FernándezPacheco R, Marquina C, Ibarra M R, de la Fuente J M, Rubiales D, Pérezde-Luque A, and Risueño M C. 2009. Nano-particle penetration and transport in living pumpkin plants: in situ subcellular identification. BMC Plant Biology 9: 45-52.

Heinonen J K and Lahti R J. 1981. Enzymatic assay of phytase. Analytical Biochemistry 113: 313-17.

Kalayu G. 2019. Phosphate Solubilizing Microorganisms: Promising Approach as Biofertilizers. International Journal of Agronomy 2019: 1-7.

Mishra R D and Ahmed M. 1987. Manual on Irrigation Agronomy. Oxford and IBH Publishing Company Pvt. Ltd.

Murphy J and Riley J P. 1962. A modified single solution method for determination of phosphate in natural waters. Analytical Chimistry Acta 27: 31-36.

Newman J. 1966. A method of estimating total root length in a sample. Journal of Applied Ecology 3:139-45.

Olsen S R, Cole C V, Watanabe F S and Dean L A. 1954. Estimation of Available Phosphorus in Soils by Extraction with Sodium Bicarbonate. U. S. Department of Agriculture Circular No. 939. Banderis, A. D., D. H. Barter and K. Anderson. Agricultural and Advisor.

Page A L. 1982. Methods of soil analysis, Part 2. (ed) Chemical and Microbiological Properties, Soil Science Society of America Journal., Inc. Madison, Wisconsin, U. S. A.

Parfsh R W. 1974. Acid Phosphatase. Journal of Histochemical Cytochemistry 9: 542-44.

Richardson A E and Simpson R J. 2011. Soil microorganisms mediating phosphorus availability. Plant Physiology 156: 989 $-96$.

Tennant D. 1975. A test of modified line intersects method of estimating root length. Journal of Ecology, 67: 995-01.

\section{How to cite this article:}

Tapan Adhikari 2019. Magnesium Oxide Nano Particles Effects on utilization of soil Phosphorus by Maize (Zea mays L.) Plant. Int.J.Curr.Microbiol.App.Sci. 8(10): 410-419. doi: https://doi.org/10.20546/ijcmas.2019.810.043 